\title{
3D VIRTUAL RECONSTRUCTIONS OF MINOAN RURAL SITES: THE CASE OF LIVARI CHEROMYLIA (EAST CRETE)
}

\author{
T. Alusik ${ }^{\mathrm{a},{ }^{*}}$, with contribution by M. Chalupka ${ }^{\mathrm{b}}$ and D. Kopernicky ${ }^{\mathrm{c}}$ \\ ${ }^{a}$ Czech Centre for Mediterranean Archaeology, Malesicka 26, CZ-10800, Prague, Czech Republic \\ ${ }^{\mathrm{b}}$ Municipality of Prague, Department of Monument Care, Jungmannova 29/35, CZ-11000 Prague, Czech Republic \\ ${ }^{\mathrm{c}}$ Benteler Automotive CZ Ltd., Skolni 713, CZ-46331, Chrastava, Czech Republic
}

KEY WORDS: 3D reconstruction, Bronze Age, Minoan Crete, Livari Cheromylia

\begin{abstract}
:
The use of 3D sophisticated visualizations and reconstructions is still not common during the process of reconstruction or recreation of the appearance of any preserved architecture of prehistoric (Bronze Age) Crete. However, the author believes that in modern archaeology the use of the up-to-date computer technologies and sophisticated software is necessary. In their opinion, in case of presenting of sites with preserved architecture a creation of ideal 3D reconstruction should become a standard feature of final publications in the near future. The author deals with the study of Minoan architecture, settlement pattern and rural aspect of Minoan Crete in the last years. In this paper, the author - in cooperation with an architect and a specialist in technical modelling - is presenting an ideal 3D virtual reconstruction of the small rural site of Livari Cheromylia (consisting of 4 main structures and several terrace walls), situated on the southern coast in the Bay of Livari, between Goudouras and Aghia Irini. The 3D reconstruction of the individual structures and the site as a whole based on the up-to-date scholarship on Minoan architecture and the actual archaeological/architectural parallels in situ as well as on the iconographical sources, is presented below.
\end{abstract}

\section{INTRODUCTION}

The use of 3D sophisticated visualizations and reconstructions is still not common during the process of reconstruction or recreation of the appearance of any preserved architecture of prehistoric (Bronze Age) Crete. In the past decades, such reconstructions were occasionally used, mainly when the ideal appearance of so-called Minoan palaces and villas was presented to tourists or general public (e.g. the reconstruction of the "Palace of Minos" at Knossos; such postcards and posters are sold to the tourists in the official museum shops). However, these artworks were always coloured hand drawings and were only rarely used in academic context. One of the most prominent artists, who created such drawings, was Kostis Iliakis (for his reconstruction of the palace of Phaistos see Davaras, n.d., plate opp. p. 64). Only recently some $3 \mathrm{D}$ reconstructions were created and used as the illustrations of scientific papers or books (see e.g. Sakellarakis and Sakellarakis, 1991, with reconstruction drawings of various structures in and around the town of Archanes, incl. some artefacts - p. 30-1, 36-9, 69, 71, 152-3, figs. 15, 19-20 (reconstruction of the various parts of the palace building), 42 (reconstruction of the grave enclosure), 45 (accurate graphic reconstruction of the ivory comb), 131 (isometric reconstruction of the shrine building with the interior in the moment of destruction)). In June 1998, a 3D reconstruction of clay architectural model from Archanes (MM III period; see e.g. Lebessi, 1976; Sakellarakis and Sakellarakis, 1991, 61, fig. 36; deposited in the Herakleion Museum) appeared on the website of the Institute of Classical Archaeology of Friedrich-Alexander University of ErlangenNuremberg (http://www.aeria.phil.unierlangen.de/ausstellung_html/lectures_html/archanes/archanes 1.html). This is the first case known to the author when special software for architectural modelling was used. In 1999, D. Preziosi and L. Hitchcock used several 3D visualizations of some types of prehistoric Aegean architecture in their book (tombs, palaces, villas: Preziosi and Hitchcock, 1999, e.g. pp. $45,50,57,80,104,111,175$, figs. 17, 22 (reconstructions of houses), 30 (reconstruction of the sc. house tombs), 45, 62 (reconstructions of the palaces), 69 (isometric plan of the sc. villa), 88 (reconstruction of the open sanctuary), 113 (reconstruction of a part of the citadel). From the graphic point of view these visualisations are line arts, but rather of technical than of artistic character.

In 2005, several versions of possible appearance of Minoan (= Cretan Bronze Age) villas at Epano Zakros and Achladia were published in "Opuscula Athiensia" journal by Greek archaeologists (Mantzourani and Vavouranakis, 2005). In this case, the last version of sophisticated software for architectural modelling and visualization was used.

The author believes that in modern archaeology the use of the up-to-date computer technologies and sophisticated software is necessary. In their opinion, in case of presenting of sites with preserved architecture a creation of ideal 3D reconstruction should become a standard feature of final publications in the near future. However, they understand that the achieving of this goal is often difficult because of objective archaeological reasons (such as the extremely bad state of preservation of the architecture and a limited number of iconographical and/or written sources for creation of a credible or at least probable reconstruction of a building or a site).

The author deals with the study of Minoan architecture, settlement pattern and rural aspect of Minoan Crete in the last years. During the surface survey projects in the last decades a lot of (several hundreds of them in author's opinion) simple rural sites consisting of one to several buildings were found. However, only a few of them were excavated or at least thoroughly documented (i.e. an exact plan was drawn and surface finds were collected, described and published). In 2008, the author participated in the Austrian project "Archäologische Geländeprospektion Südostkreta" - a surface survey and documentation of Minoan to recent sites in far south-east Crete in the region of Ziros (nomos Lasithi, eparchy of Sitia) directed 
by Dr. Norbert Schlager (University of Vienna). The author's task in this project was the re-examination, supplementary documentation and co-publication of small MM-LM rural site of Livari Cheromylia (consisting of 4 main structures and several terrace walls), situated on the southern coast in the Bay of Livari, between Goudouras and Aghia Irini (a complete publication of the project results will appear in ÖJh 2010, currently in press - see Alusik, in press; Schlager et al., in press). In this paper, the author - in cooperation with an architect (M.Ch.) and a specialist in technical modelling (D. K.) - is presenting an ideal 3D virtual reconstruction of the individual structures and the site as a whole, based on the up-todate scholarship on Minoan architecture and the actual archaeological/architectural parallels in situ as well as on the iconographical sources. Several versions of the appearance of the structures and the site will be presented below.

The 3D virtual ideal reconstruction of the site of Livari Cheromylia is the first step of the new project led by the author on the 3D reconstructions of rural, or in general "non-palatial", sites of Minoan Crete - called "Non-palatial Minoan Crete 3D Visualization Project" - which will be based and presented within a few weeks on the website of the "Czech Centre for Mediterranean Archaeology" (www.ccma.cz).

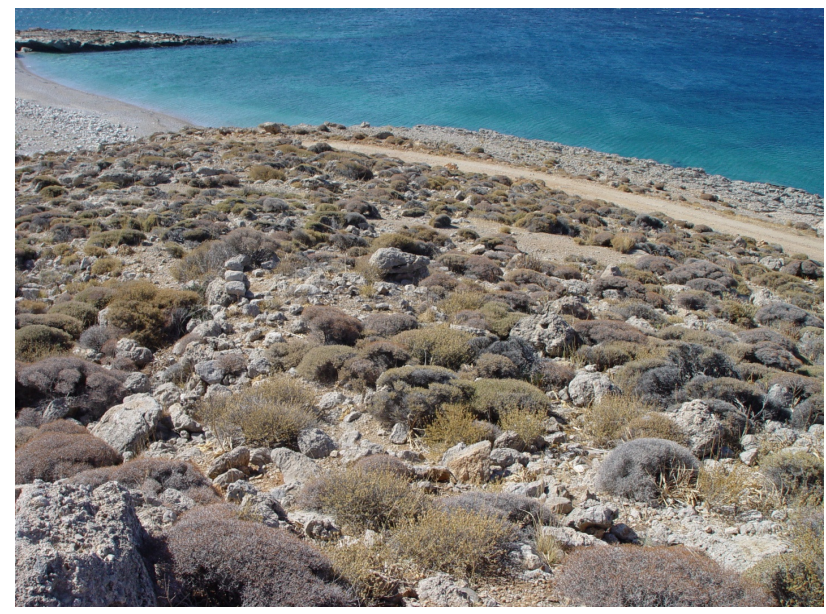

Figure 1. The photo of the site of Livari Cheromylia (view from the north; photo by the author).

\section{THE SITE OF LIVARI CHEROMYLIA}

Livari Cheromylia (Fig. 1-3), a MM-LM site, is located to the west of the bay of Livari, resting on the slopes of a low hillock mainly on its south and west sides. It rises several dozen meters at the north-west above the shoreline of the Libyan Sea. The east and north-east sides of the hillock are steep, whereas the western slope, also formed by several terraces, is gentler and the ridge merges naturally with the adjoining one. At the south and south-west a modern dirt road (chomatodromos) runs along the foothill. This southern slope, in the east, suddenly falls into the sea with a steep 5 meter cliff. The residential area of the prehistoric settlement forms a total of four clearly defined buildings (Buildings I, II, IV and Structure V) built from massive blocks of local stone, with three of them consisting of more than one room, and 12 indisputably identified and clearly visible wall segments. All these architectonic remains with a high concentration of surface finds, mostly ceramic, are located in an area ca. 80-90 x $60 \mathrm{~m}$ across.
Building I (Fig. 4-8) is situated in the upper part of the site, about 16-20 m above sea level and consists of three rooms (13 ). Room 1 is located in the north-eastern part of the building and defined by the points A, B, J, I. Room 2 is considered to be the largest space of the whole complex, defined by points I, J, F, $\mathrm{G}$ and $\mathrm{H}$; its dimensions are $7.80 \times 9.20 \mathrm{~m}$. The west side of room 1 adjoins the slightly smaller space no. 3 (approx. 4 x $6 \mathrm{~m}$; D-C-E-J), also roughly rectangular.

Building II is located approximately $15 \mathrm{~m}$ southwest below Building I and several meters above the dirt road. It is composed of four rooms (1-4). The most northerly room 1, defined by points $\mathrm{G}-\mathrm{H}-\mathrm{I}-\mathrm{J}-\mathrm{K}$, forms an incomplete not quite regular tetragon with dimensions approximately $8 \times 4.60 \mathrm{~m}$. South of this area the remains of room 2 are located, (ca $8.50 \mathrm{x}$ $11 \mathrm{~m}$; A-B-C-D), the largest part of the building. Room 3 is attached to the eastern wall of room 2 . It has almost square floor plan (ca $3.50 \times 4 \mathrm{~m}$ ). Room 4 is defined by points $\mathrm{B}, \mathrm{N}, \mathrm{O}$ and $\mathrm{P}$, with dimensions approx. $3.80 \mathrm{~m} \times 3.60 \mathrm{~m}$.

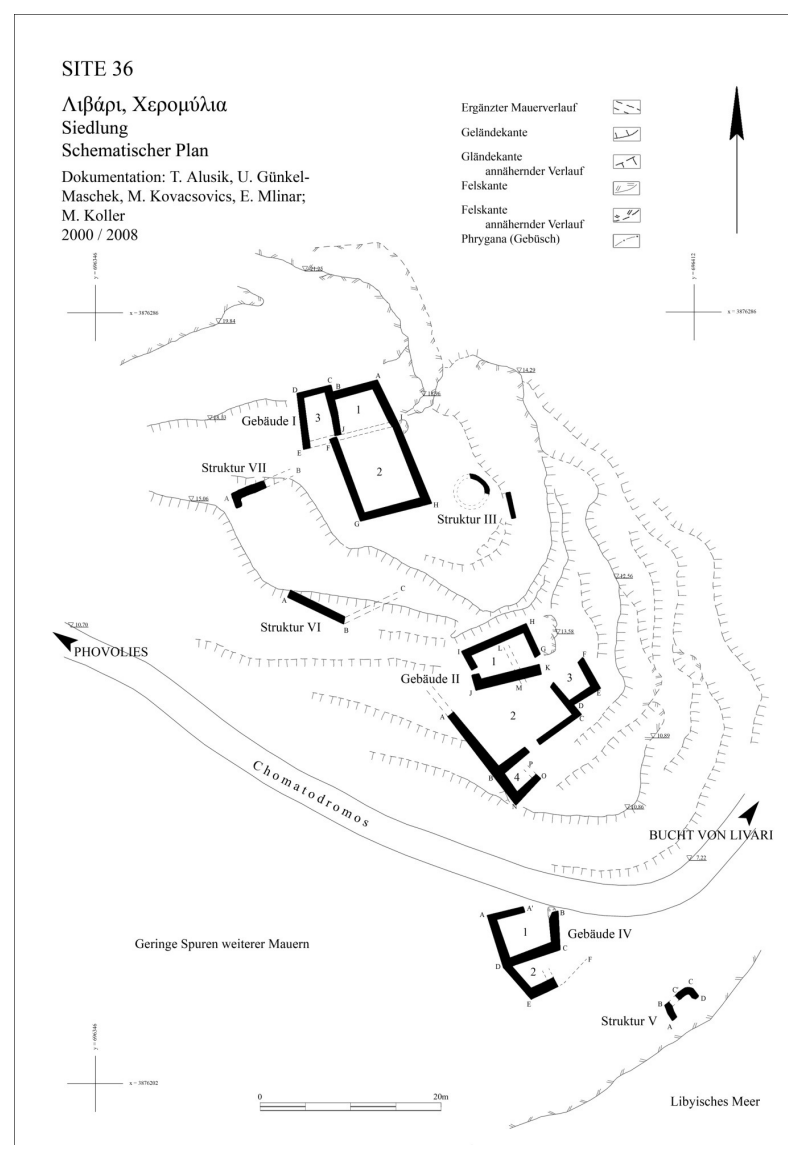

Figure 2. The schematic plan of the site of Livari Cheromylia created by N. Schlager et al. (will appear in ÖJh 2010). () Norbert Schlager.

The remaining two preserved buildings, Building IV and Structure V, are located below the dirt road. Building IV has a nearly rectangular shape and consists of two rooms. The main part of the building, room $1\left(\mathrm{~A}-\mathrm{A}^{\prime}-\mathrm{B}-\mathrm{C}-\mathrm{D}\right)$ has almost a square floor plan with one side around $6.50 \mathrm{~m}$ long. Room 2 is situated south of room 1 and is formed only by its external western (ca $3.80 \mathrm{~m}$ ) and southern (ca $7.90 \mathrm{~m})$ walls. Structure $\mathbf{V}$, defined by points $\mathrm{A}-\mathrm{B}-\mathrm{C}-\mathrm{C}^{\prime}-\mathrm{D}$, has a very simple 
rectangular floor plan with dimensions approximately $3.50 \mathrm{x}$ $2.50 \mathrm{~m}$. It is formed by a group of four huge limestone blocks, clustered in the shape of the letter $\Pi$, creating a three-sided enclosure.

After this short description of the site discussed the process of creation of $3 \mathrm{D}$ reconstruction will be described. But first the iconographical sources and architectural parallels (i.e. archaeological sources) will be presented.

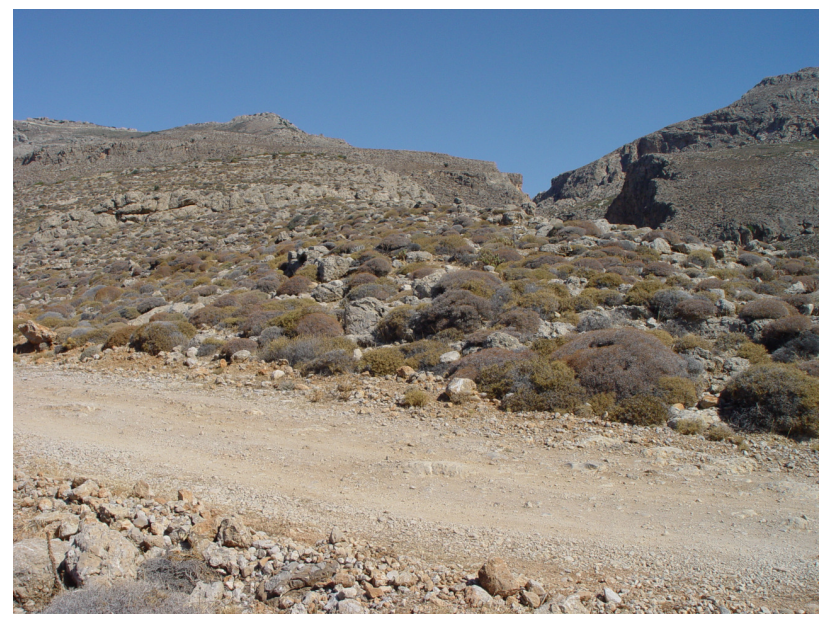

Figure 3. Livari Cheromylia, view from the south (photo by the author).

\section{THE PARALLELS AND SOURCES FOR RECONSTRUCTION}

Since in most cases the Minoan architecture is preserved only up to several courses of masonry, the process of reconstruction of any structure is very difficult and, unfortunately, it is necessary to rely on the iconographical sources and architectural parallels to a great extent. From these reasons we are presenting here two varieties of the upper/second floor - a "closed/walled" variety, where a usual walled (second) storey with flat walkable roof stands on/above a ground floor; and an "open" variety, where the upper floor has a form of a verandah covered with a simple and light flat roof (see e.g. Hallager, 1990).

The iconographical sources show us a lot of important architectural details (such as the shape of windows and doors or a form and composition of ceilings and roofs, the appearance of columns and pillars), indicate the construction materials that were used (stone, wood, (mud)bricks), but mainly they depict the shape and appearance of the upper part of a building, including the number of floors. Regarding the religious themes of Minoan iconography, the sacral architecture or the whole towns that served as a background for religious events were most often represented. The best representations of architecture are of course preserved on Minoan frescoes, however, some other works of art are also very important: the architectural models (see above the house model from Archanes), the small relief plaques (sc. Town Mosaic from Knossos, Middle Minoan IIB(-III?); see e.g. Evans, 1921, 301-14, fig. 223-4, 226, 22830) and the sealings (e.g. sc. Master Impression from Chania, Late Minoan I-II; see e.g. Hallager, 1985). For example, on the miniature frescoes from the palace of Knossos (e.g. on the sc. Grandstand/Temple Fresco, MM IIIB/LM IA; see e.g. Evans, 1930, 47, fig. 28-34, 36, col. pls. XVI-XVII; Cameron and
Hood, 1967, pls. B, fig. 1a, b, II, IIA) the form and composition of the roof of the (tripartite) shrine is visible. One of its important composition elements, the small coloured circles, was interpreted in most cases as rounded beam ends, on which the flat roofing is laid. Another fresco fragment from Knossos (sc. Women looking out of a casement, MM IIIB/LM IA; see e.g. Evans, 1930, 602, fig. 375; Cameron and Hood, 1967, pl. IV, fig. 15) documents a standard practice of the bordering of window openings with wooden frames (which is confirmed by the preserved façades (with windows) of houses in Akrotiri on Thera - see below in this chapter). Many structures are represented on the frescoes (painted in Minoan style) from the Minoanizing settlement at Akrotiri on Thera island. On the miniature frieze from the sc. West house, room 5 (LM IA, see e.g. Morgan 1988; Doumas 1992), three towns are depicted. Especially the third one (usually called "Arrival town") contains a lot of high and imposing buildings. In the "Meeting on the hill" scene on the northern wall of the room a simple building with three doorways is painted, which best illustrates the simple rural environment of the countryside. But presumably the most important iconographical source is the house model from Archanes (see above), whose basic architectural concept was used in our reconstruction of the Building II - i.e. the usual walled ground floor (in case of Cheromylia Buildings built from massive blocks of stone) and the "open" upper floor in the form of a covered verandah.

As the architectural parallels it is necessary to mention especially the numerous group of similar buildings (or sites) built mainly from massive or "megalithic" blocks of the local stone (limestone or conglomerate; this building technique is usually marked as "cyclopean" or rather "ogolithic" masonry see Beckmann, in press; Beckmann, 2009), however, mud bricks were often used (most probably in upper floors/courses of walls), as the fragments of them on the surface of sites indicate. These structures are in most cases labelled as "Rural Villas", "Megalithic Farmsteads" (for a survey of these structures in East Crete see Schlager 2006), or "Guard Houses" for which an agricultural and/or defensive function may be presumed (for basic information and overview of guard houses see Tzedakis et al., 1989; Chryssoulaki, 1999; see also Alusik, 2007, ch. II.3). Also many small and simple "rural" sites consisting of a few such buildings as well as many terrace walls or periboloi (mainly in the vicinity of many guard houses, e.g. at Choiromandres: Tzedakis et al., 1990; Brown (ed.), 2001, 321-323; Alusik, 2007, 27-29) are very similar from the architectonic point of view. In Crete (mainly in the eastern part on the outer slopes of Lasithi Mountains and in Sitia region) several hundreds of sites and structures of all these types were described, but only several dozens of them were at least partially published (i.e. a plan was drawn) and only a few of them were excavated (e.g. the guard houses in Choiromandres and Karoumes; see e.g. Alusik, 2007, 32-3 (with further bibliography); the rural villa in Epano Limnia - see e.g. Alusik, 2007, 25-6 (with further bibliography); and rural sites in Agios Antonios near Kavousi - Haggis 2005, 95-98, fig. 27, pl. 1112A). These buildings and sites originate mostly in MM-LM. In some sites the parts of buildings are still preserved up to the height of around $2 \mathrm{~m}$.

The well-preserved houses at Akrotiri on Thera island are other important architectural sources for our reconstruction. During the eruption of the volcano (that in fact forms the island) in the developed phase of LM IA the Minoanizing town was covered by the volcanic sediments and the buildings were conserved since that time. A lot of imposing houses built from halftimbered masonry with the façades up to the height of several 
floors were preserved. The stone was used for the construction of the ground floor and the mudbricks, or the rubble masonry, for the upper floor(s). All house walls were reinforced with timbers to get the better fixity and stability. The houses (which are usually labelled as xestai) show us a lot of important architectural details, such as windows and doors, staircases and other interior elements. Therefore, the appearance of the most of windows in our reconstruction corresponds mainly to the actual preserved examples at Akrotiri and was influenced only to a limited extent by the iconographical sources. Also in some doors in our reconstruction of the two main Buildings in Cheromylia the similar concept as at Akrotiri was used, i.e. the vertical doorjambs made of wood.

\section{THE CONSTRUCTION MATERIAL AND THE CONSTRUCTION TECHNIQUE OF THE INDIVIDUAL PARTS OF THE STRUCTURES}

\subsection{The material}

The basic construction material of the ground floor walls (and possibly of ceiling supports/pillars, too) was of course a stone massive and unworked, eventually also roughly hewn blocks of local limestone and/or conglomerate (for the use of stone in Minoan architecture see e.g. Shaw, 1973). Most probably, other building materials besides stones would have been used such as mud bricks for the upper courses or floors, wood for reinforcement, roof support, ceiling joists, and soil for roofing. In our reconstruction the whole ground floor is made of stone and only the upper floor of mudbricks in the wooden frame (half-timbered masonry) in case of the closed/walled variety, or mostly from the wood with the low balustrade of mudbricks (or wood) in case of the open variety.

\subsection{The general principles and the construction technique of the individual parts of the structures}

For the foundations massive stone blocks set often directly on bedrock or on a levelling layer from small stones were used in Minoan architecture. Eventual rock projections were included in the wall as stable points and were "bound" to the big blocks by means of small stones. As was already stated, for the ground floor walls massive blocks of local stone, either coarse or only roughly worked, were used. This construction technique is often labelled as "(Minoan) Cyclopean masonry", but because of possible confusion with Mycenaean Cyclopean masonry it is sometimes referred to as "megalithic" or "ogolithic" masonry (for the new suggested terminology see Beckmann, 2009, and Beckmann, in press). By all means, the individual blocks (often around $1 \mathrm{~m}$ long) are set upon each other without any binding substance and the interstices among them are sometimes filled with small stones. The outer façade is very often built from bigger blocks than the inner one. The floors of the ground floor possibly consisted of hard packed earth. For the floor of the upper storey the simple wooden planks were used in our reconstruction. The interior (Fig. 5) is in our reconstruction reduced only to the depiction of windows, doors and several construction elements, such as simple wooden staircase leading to the upper floor (and further up to the roof) and ceiling supports (both made from stone blocks and wood). The inner façades were most probably rendered with simple lime or clay plaster. The ceilings were most probably composed from several layers: first horizontal rounded beams, on which palm leafs, reed or straw were laid as a levelling course. Such practice is documented by the pieces of burnt earth with the imprints of palm leafs or reed which were found during the excavations of some sites (e.g. in Myrtos-Phournou Korifi: Warren, 1972; Preziosi and Hitchcock, 1999, 50, fig. 22). Packing of soil on it is questionable in the closed/walled upper storey, but can be used in the case of "open" variety. In author's opinion the highest layer of the ceilings, i.e. the upper walkway surface of the first storey floor, was made from simple wooden planks. The walls of the upper floors were most probably built from mudbricks and the walls as a whole were probably also reinforced with timbers (i.e. half-timbered masonry) as at Akrotiri. The mudbricks were most probably rendered on the outer side with a simple lime plaster. Although the specifics of roof construction are unknown, it is highly probable that roofs were flat. Not only is this the easiest to construct but it also has functional advantages in that it can be used as work space or a sleeping area in summer months (Fig. 6). Considering the large dimensions of the majority of the rooms, some of them in theory might have been hypaethral, or otherwise have required beams, posts or columns to support roofing. However, in our reconstruction all rooms are roofed. In case of closed/walled variety the construction of the roofs was probably not too different from the construction of the ceilings: first the layer of horizontal rounded beams, then the covering layer of palm leafs, reed or straw and finally the thick layer of hard packed earth. On the other hand, the roofs of the open variety were most likely simple and light (see above the house model from Archanes). Several piers or columns supported the basic frame of beams covered with reed or similar light material. Reed is still used in "kamaras" (verandah-like spaces) of present-day Greek country houses. Terrace retaining walls were built in the same way as the ground floor walls.

\section{THE ARCHITECTURAL RECONSTRUCTION}

In this chapter the process and the result of the reconstruction of the particular parts of the individual buildings in the site of Livari Cheromylia will be discussed. The reconstruction was done in two different software applications: Google SketchUp Pro, version 7.0.8657, software designed mainly for modelling of architectural structures, and Cinema 4D, release 11, software designed for modelling of objects of any kind.

During the reconstruction process the author started from personal experiences and photos and plans of the site. In the resulting reconstruction - the general view of the site - the individual buildings were set into the photo in places which best correspond to their real location (Fig.8). During the creation of $3 \mathrm{D}$ virtual reconstructions of the individual buildings these were set into the software-modified terrain and in their closest surroundings the terrace walls occur (see e.g. Fig. 4), whose location and course in most cases roughly correspond to the real situation in situ (there are a lot of short sections of terrace walls on the surface of the site built from massive masonry, which were, however, not drawn and described).

The ground floors of all Buildings were reconstructed in stone (massive irregular blocks), the texture, that was used for the surface, was created and adjusted on the basis of photos of several guard houses from East Crete. As the Building I was built on the slope, the floor of the ground storey was most probably sloping; this is mainly the case of room 2 . The height of this room on the ground floor level was therefore different higher on the southern side and lower on the northern one. For this reason it is highly probable in author's opinion that the ground floor was used as a storage space or workshop and only on the upper floor there were habitation rooms. On the ground floor level of all buildings windows and entrances were placed 
in some conjectural locations. However, locating entrances is very problematic as no traces of thresholds or doorframes were found, as they were both likely made of wood. In our reconstruction some doorframes were created in stone - on the basis of parallels with some guard houses - and the other ones with wooden vertical jambs and stone lintel. In author's opinion the following location of entrances in all four Buildings of the site is most likely from the architectonic point of view (there are some interruptions in the courses of walls): in Building I in room 3, wall EF, and in room 2, wall GH; in Building II (which is more open to its surroundings) in room 2 , wall $\mathrm{BC}$, and in room 1, walls IJ and HGK. In our opinion, there was a staircase located in room 4. In Building IV, the most probable location of entrance to the room 1 was in the wall CD. Structure V was in our opinion accessible from the southeast, so the entrance was most probably located somewhere between the points A-D. The location and appearance of the windows is, unfortunately, only conjectural. In our reconstruction we were particular about placing at least one window to each room. We reconstructed simple square windows of smaller dimensions to the ground floors and larger square windows divided by horizontal crossbars into three segments to the upper floors (in case of closed/walled variety). All window frames and crossbars were created from wood. The appearance of windows in our reconstruction corresponds to the preserved ones at Akrotiri and to the iconographical sources.

As was already stated above, the upper floors were reconstructed as two different versions. In the closed/walled variety mudbricks set in the wooden frame (i.e. half-timbered masonry) were used; the outer façades were most likely plastered. The roof was thicker than the ceiling of the ground floor and was most likely also walkable. For this reason its edges are bordered by the low balustrade from mudbricks and close to it an access hole (of a staircase from the lower floors) with a simple porch was located. The open variety, on the other hand, uses the walkable area of the roof of the ground floors. The upper floors have no usual (walled) walls, but only a low balustrade or simple wooden railing and poles or columns set on the perimeter (or in case of long dimensions/distances also in the area of the open space), which supported the wooden frame of the light roof covered by the reed, straw, thatch or similar simple material. Again an access hole is here too, of course.

Structure V was different from other three Buildings because of its dimensions and the overall character and served most likely as a workshop or had similar specific function (kitchen?). From these reasons it was reconstructed as a simple single-storey structure with wide entrance.

\section{CONCLUSIONS}

It is necessary to repeat here that our $3 \mathrm{D}$ reconstruction of Livari Cheromylia presented in this paper is an ideal result of a combination of the state of preservation of the site, the state of knowledge of Minoan rural architecture and the testimony of the iconographical sources and architectural parallels. During the process of creation of it we tried to adhere to the sources and parallels mentioned above in a maximal extent; unfortunately, it was not always possible. Due to the bad state of preservation of Minoan rural architecture and the site discussed we have to admit we proceeded in certain moments purely according to our discretion, especially on the basis of our architect's (M.Ch.) opinion. This is the case of the location and the appearance of the doors (due to the better clearness two versions - made only of stone and the "composite" one made of wood and stone - are presented) and windows. The form and appearance of the upper floors and their two varieties (closed/walled and open/verandah) correspond to the iconographical sources and architectural parallels and result from the up-to date state of the research. Again for the better clearness both varieties are presented here, one on each of the two main Buildings. In some points our reconstruction might be controversial, but the real and exact appearance of the individual buildings of this site will stay, unfortunately, unknown forever.

The author hopes that in Aegean archaeology the 3D reconstructions of architecture created by sophisticated software in cooperation with architects or modelling specialists will be used in greater extent in the near future. They will be very glad, if this paper contributes to the widening of this phenomenon. As was already stated above, the $3 \mathrm{D}$ virtual reconstruction of the site of Livari Cheromylia is the first step of the new project led by the author on the 3D reconstructions of rural, or in general "non-palatial", sites of Minoan Crete (called "Non-palatial Minoan Crete 3D Visualization Project"), which will be based and presented (within a few weeks) on the website of the "Czech Centre for Mediterranean Archaeology" (www.ccma.cz).

\section{BIBLIOGRAPHY:}

Alusik, T., 2007. Defensive Architecture of Prehistoric Crete. Archaeopress, Oxford.

Alusik, T., in press. SITE 36. Livari, Cheromylia 1. Topography and Architecture. In: N. Schlager et al., in press. Aspro Nero, Agia Irini, Livari in Sïdostkreta: Dokumentation 2008. ÖJh $79 / 2010$.

Beckmann, S., 2009. War or Peace? Middle Bronze Age Cyclopean/Megalithic Structures in the Area of Agios Nikolaos, Crete (Abstract). Paper presented at the "Round Table on Bronze Age Aegean Warfare" held at the National and Kapodistrian University of Athens, $12^{\text {th }}$ and $13^{\text {th }}$ December 2009. http://www.combat-archaeology.org/abstracts.pdf (accessed 5 Feb. 2011)

Beckmann, S., in press. War or Peace? Middle Bronze Age Cyclopean/Megalithic Structures in the Area of Agios Nikolaos, Crete (Abstract). In: K. Grigoropoulos and A. Papadopoulos, eds. Acts of the "Round Table on Bronze Age Aegean Warfare" held at the National and Kapodistrian University of Athens, $12^{\text {th }}$ and $13^{\text {th }}$ December 2009. INSTAP Academic Press, Philadelphia.

Brown, A. ed., 2001. Arthur Evans's Travels in Crete, 1894 1899. Archaeopress, Oxford.

Cameron, M. S. A. and Hood, S., 1967. Sir Arthur Evans, Knossos Fresco Atlas. Gregg Press, Farnborough.

Chryssoulaki, S., 1999. Minoan Roads and Guard Houses - War Regained. In: R. Laffineur, ed. Polemos. Le contexte guerrier en Egée a l'age du bronze. Actes de la 7 e Rencontre égéenne internationale, Université de Liége, 14 - 17 avril 1998. Université de Liége, Liége - Austin, pp. 75-84.

Davaras, C., no date. Phaistos - Hagia Triada - Gortyn: Brief Archaeological Guide. Hannibal Publishing House, Athens.

Doumas, Ch., 1992. The Wall-Paintings of Thera. The Thera Foundation - Petros M. Nomikos, Athens. 
Evans, A. J., 1921. The Palace of Minos. A Comparative Account of the Successive Stages of the Early Cretan Civilisation as Illustrated by the Discoveries at Knossos. Volume I. Thames and Hudson, London.

Evans, A. J., 1930. The Palace of Minos. A Comparative Account of the Successive Stages of the Early Cretan Civilisation as Illustrated by the Discoveries at Knossos. Volume III. Thames and Hudson, London.

Haggis, D. (with contributions by Michael W. Morris, John T. Ammons, Michael E. Timpson, John E. Foss, Margaret S. Mook, Peter M. Day, Louise Joyner, Evangelia Kiriatzi, and Maria Relaki), 2005. Kavousi I: The Archaeological Survey of the Kavousi Region. INSTAP Academic Press, Philadelphia.

Hallager, E., 1985. The Master Impression. Paul Åströms Förlag, Göteborg.

Hallager, E., 1990. Upper Floors in LM I Houses. In: R. Laffineur, ed. Aegaeum 6. Annales d'archéologie égéenne de l'Université de Liège. Université de Liège, Liège, pp. 281-92.

Lebessi, A., 1976. O oikiskos ton Archanon. AE, 1976, pp. 1243.

Mantzourani, E. and Vavouranakis, G., 2005. Achladia and Epano Zakros: a re-examination of the architecture and topography of two possible Minoan villas in east Crete. OpAth, 30, pp. 99-125.
Morgan, L., 1988. The Miniature Wall Paintings of Thera: A Study in Aegean Culture and Iconography. Cambridge University Press, New York.

Preziosi, D. and Hitchcock, L. A., 1999. Aegean Art and Architecture. Oxford Universitx Press, Oxford.

Sakellarakis, J. A. and Sapouna-Sakellarakis E., 1991. Archanes. Ekdotike Athenon S.A., Athens.

Schlager, N. 2006. "Cyclopean" or "Megalithic" Buildings in East Crete: Distribution, Form, Date, and Function. In: E. Tampakaki and A. Kaloutsakis, eds. Acts of the $9^{\text {th }}$ Cretological Congress (Elounda 2001), Vol. A3, Etairia Kritikon Istorikon Meleton, Herakleion, pp. 365-78.

Schlager, N. et al., in press. Aspro Nero, Agia Irini, Livari in Sïdostkreta: Dokumentation 2008. ÖJh 79/2010.

Shaw, J. W., 1973. Minoan Architecture: Materials and Techniques. ASAtene 49 (New Series 33), 1971 [1973].

Tzedakis, Y., Chryssoulaki, S., Venieri, Y. and Avgouli, M., 1990. Les Routes Minoennes: Le poste de Choiromandres et le controle des communications. $B C H, 114,43-65$.

Tzedakis, Y., Chryssoulaki, S., Voutsaki, S. and Venieri, Y., 1989. Les Routes Minoennes: Rapport Préliminaire - Défense de la Circulation ou Circulation de la Défense? $B C H, 113,43-$ 75 .

Warren, P. M., 1972. Myrtos: An Early Bronze Age Settlement in Crete. Thames and Hudson, London.

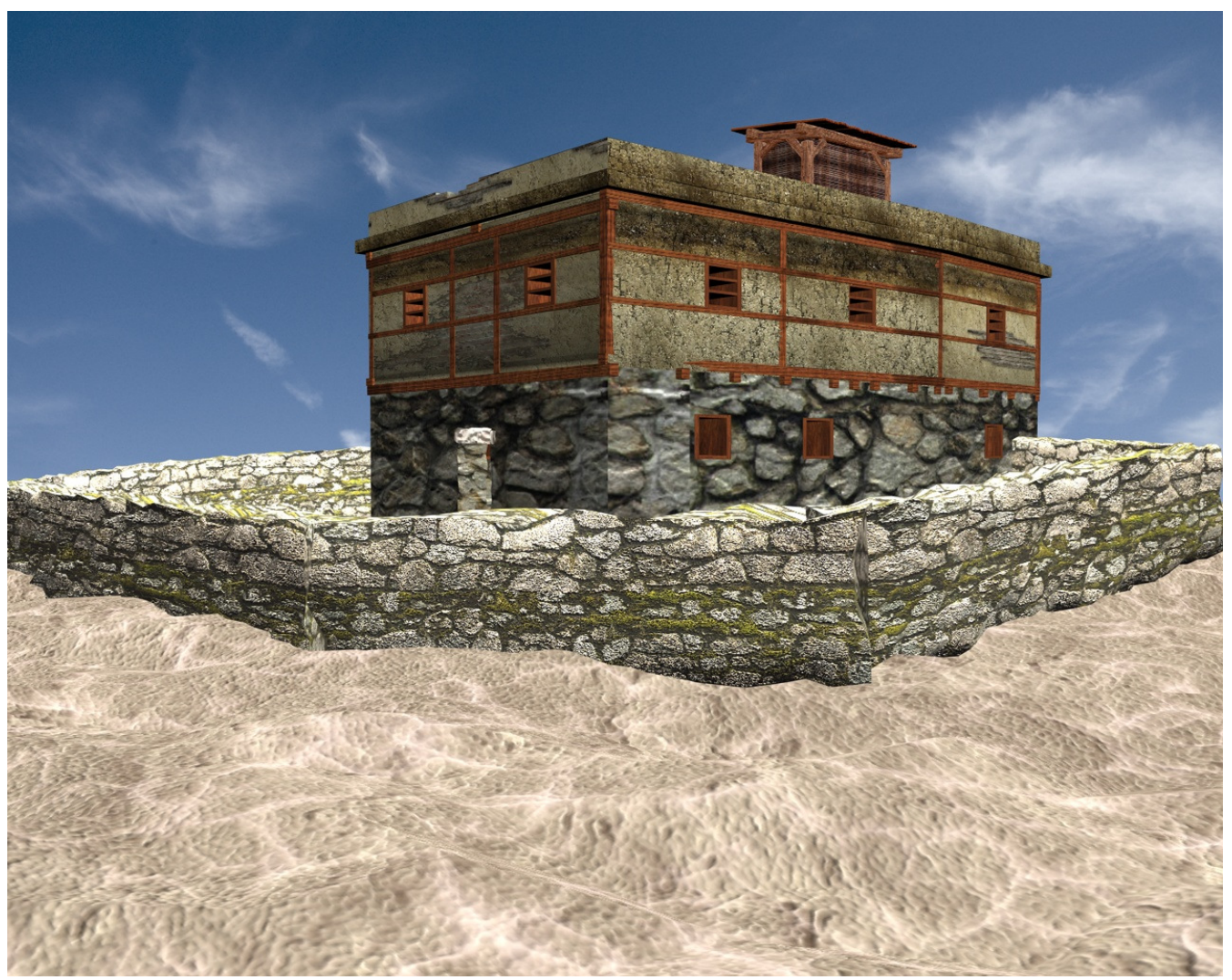

Figure 4. 3D reconstruction of Building I (closed/walled variety), set into the software-modified terrain, view from the southeast. Low walls are more or less conjectural. Created in Cinema 4D. 


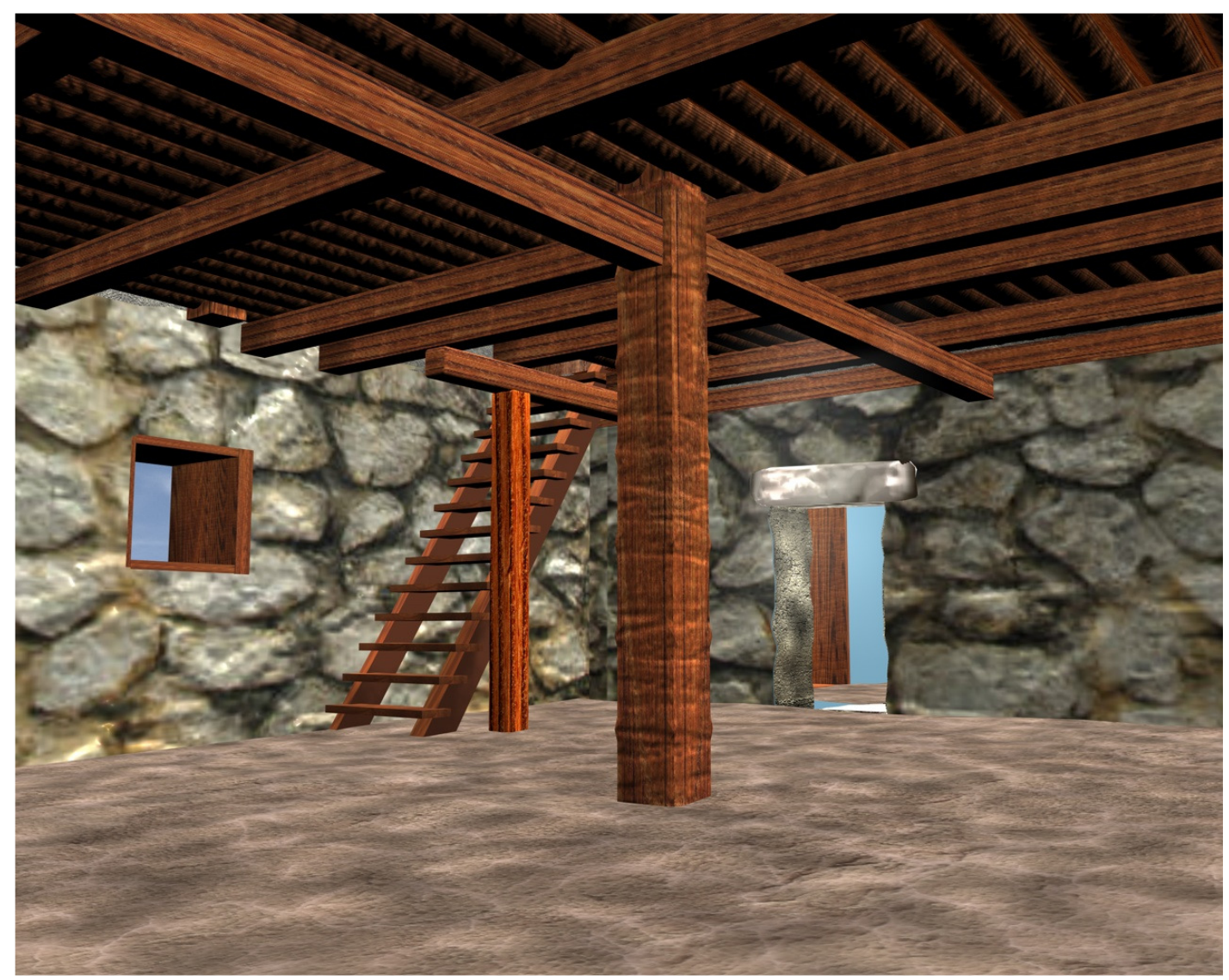

Figure 5. The interior of Building I. All interior details are conjectural. Created in Cinema 4D.

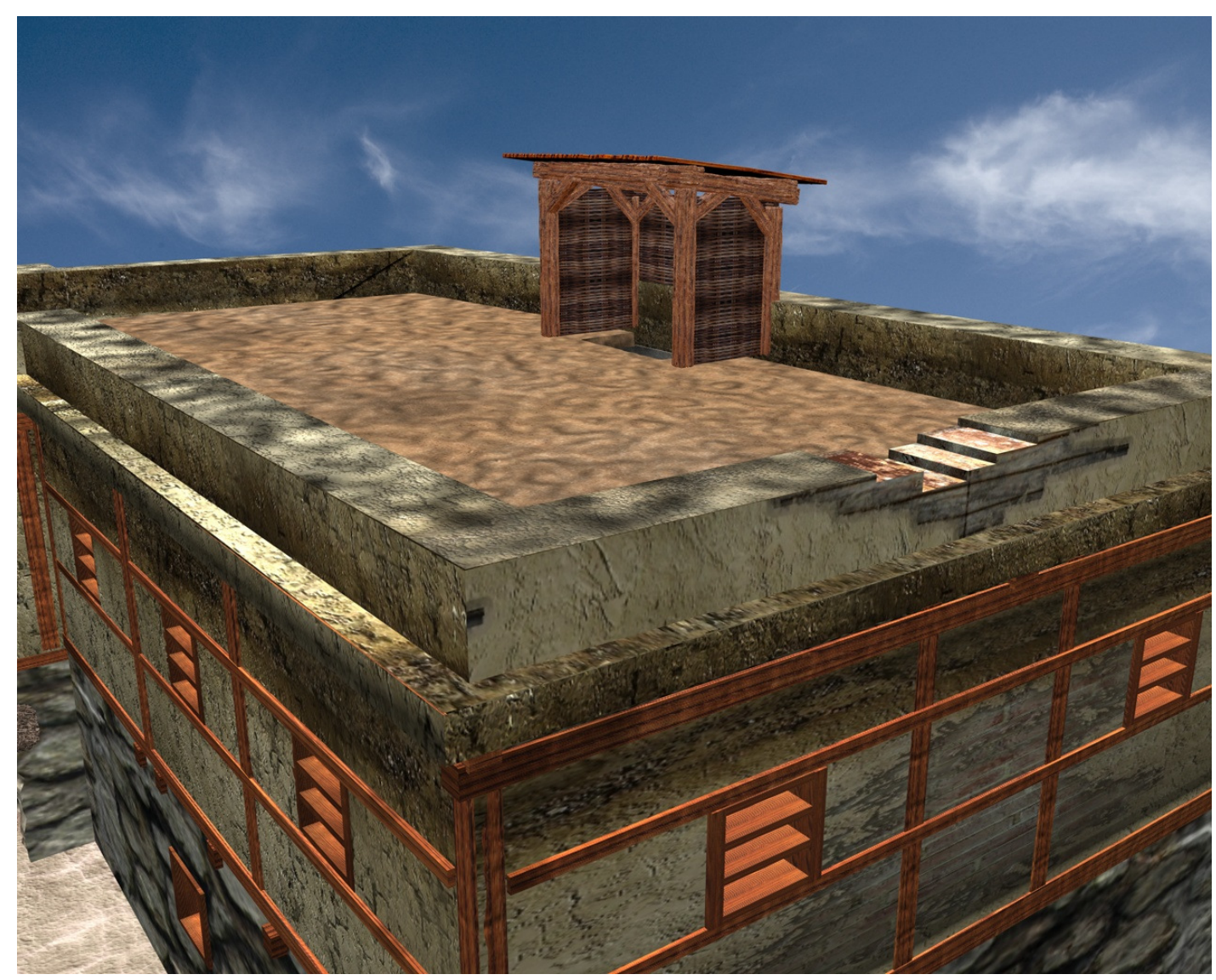

Figure 6. The roof of Building I (closed/walled variety), with the low balustrade and covered access hole. Created in Cinema 4D. 


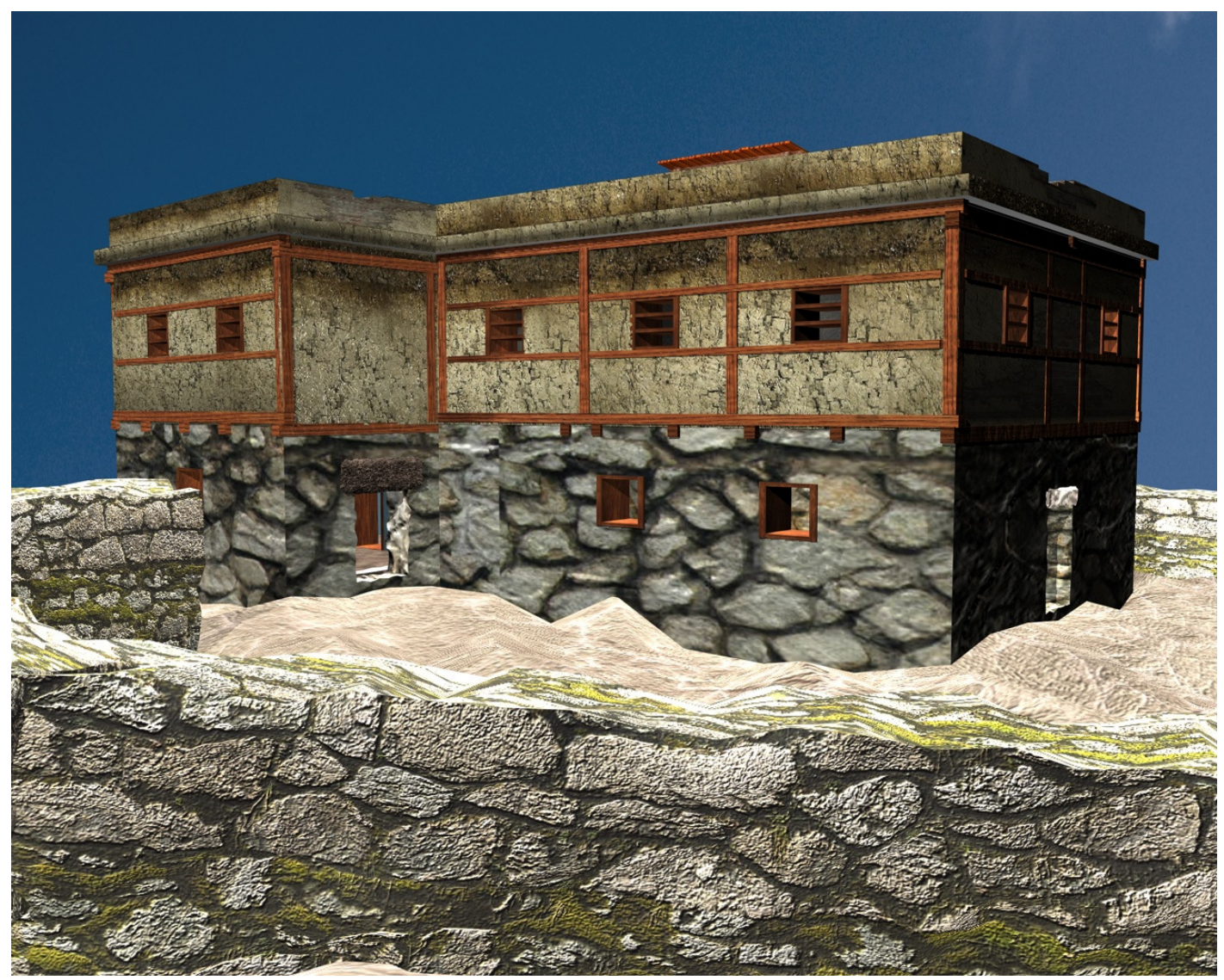

Figure 7. 3D reconstruction of Building I, set into the software-modified terrain, view from the southwest. Created in Cinema 4D.

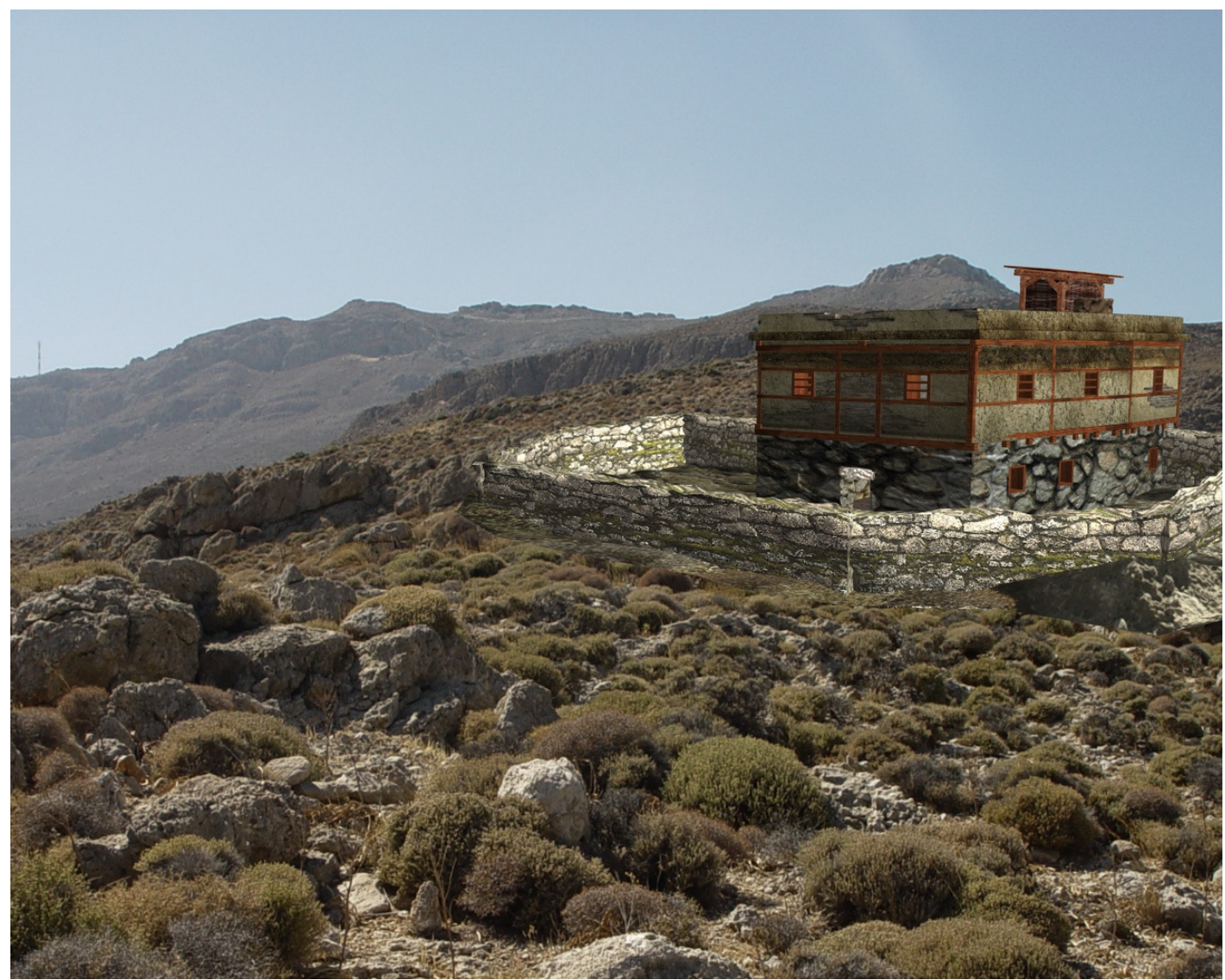

Figure 8. 3D reconstruction of Building I set into the real photo, view from the southeast. 